\title{
STRATEGI PENGEMBANGAN EKONOMI WILAYAH BERBASIS AGROINDUSTRI DI KAWASAN ANDALAN KANDANGAN KALIMANTAN SELATAN
}

\section{REGIONAL ECONOMIC DEVELOPMENT STRATEGY BASED AGRO-INDUSTRIES IN KEY REGION KANDANGAN SOUTH OF KALIMANTAN}

\author{
Dewi Siska, Setia Hadi, Muhammad Firdaus, dan Said \\ Fakultas Ekonomi dan Manajemen-Institut Pertanian Bogor \\ Badan Penelitian Pengembangan Daerah Provinsi Kalimantan Selatan \\ Jl. Jendral Sudirman Nomor 19 Banjarmasin \\ Telp: (0511)3354220 \\ Dikirim: 13 Februari 2015 Direvisi: 27 Maret 2015 Disetujui: 23 Mei 2015
}

\begin{abstract}
Abstrak
Agroindustri menjadi pilar utama dalam pembangunan di Kalimantan Selatan, hal tersebut terdapat dalam RPJPD tahun 2005-2025. Kawasan Andalan Kandangan sebagai salah satu dari tiga kawasan andalan di Kalimantan Selatan yang potensial dikembangkan untuk mendorong pertumbuhan ekonomi melalui kegiatan industry berbasis pertanian (agroindustri). Konsep agroindustri selain diharapkan dapat mendorong pertumbuhan ekonomi sekaligus dapat mewujudkan distribusi pendapatan yang merata. Penelitian ini bertujuan untuk ; (1) mengidentifikasi perkembangan ekonomi wilayah di Kawasan Andalan Kandangan, (2) mengidentifikasi komoditas unggulan, (3) mengidentifikasi sarana penunjang agroindustri, dan (4) merumuskan strategi pengembangan wilayah berbasis agroindustri. Analisis entropi menunjukkan perkembangan ekonomi Kawasan Andalan Kandangan cukup berkembang yang didominasi oleh sektor pertanian, yaitu subsektor tanaman bahan makanan. Analisis LQ dan SSA menunjukkan tanaman padi dan jagung menjadi komoditas unggulan. Sarana prasarana pendukung kegiatan agroindustri sangat kurang. Rumusan strategi dalam penelitian ini yaitu peningkatan infrastruktur atau sarana prasarana yang dapat memperlancar konektivitas antar wilayah di Kawasan Andalan Kandangan dan pemerintah sebagai aktor utama pengembangan agroindustri.
\end{abstract}

Kata kunci: agroindustri, kawasan andalan, pengembangan wilayah

\begin{abstract}
Agroindustry has become the main pillar in South Kalimantan development, it can be found in RPJPD 2005-2025. Kandangan mainstay region as one of three leading region in South Kalimantan which potentially improved to push economy growth through agriculture based industry activity (agroindustry). The concept of agroindustry a side is expected to drive economic growth as well as to realize the equitable distribution of income. This research ains to : (1) identify to economic development of the region in Kandangan mainstay regions, (2) identify the main commodity, (3) identify means of supporting agroindustry, and (4) formulating development strategies based agroindustrial region. Entropy analysis shows the development of the economy sufficiently developed in Kandangan mainstay region dominated by the agricultural sector, namely food crops subsector. LQ an SSA analysis shows corn and rice crops become competitive commodities.There are only few of supporting infrastructure agroindustrial activities. Strategy formulation in the research is the improvement of infrastructure or infrastructure that can facilitate inter regional connectivity in the region mainstay Kandangan and the government as the leading actor agroindustry development.

Keywords: agroindustry, mainstay region, regional development
\end{abstract}

\section{PENDAHULUAN}

Sektor pertanian dalam pembangunan ekonomi daerah menjadi salah satu sektor yang penting sebagai upaya mensejahterakan masyarakat. Sektor pertanian berperan pada: (1) penyedia pangan untuk pemenuhan kebutuhan yang semakin meningkat, seiring dengan pertumbuhan penduduk; (2) meningkatkan permintaan produk industri, sehingga perlunya perluasan sektor sekunder dan sektor tersier; (3) meningkatkan devisa untuk impor barang- barang modal bagi pembangunan melalui ekspor hasil pertanian secara terus menerus; (4) meningkatkan pendapatan desa untuk dimobilisasi pemerintah; serta (5) memperbaiki kesejahteraan rakyat pedesaan (Jhingan, 2012).

Rancangan Pembangunan Jangka Panjang Daerah (RPJPD) 2005-2025 Provinsi Kalimantan Selatan, menempatkan sektor pertanian sebagai bagian penting dalam pembangunan. Melalui visi RPJPD yaitu :"Kalimantan Selatan Maju dan Sejahtera Sebagai Wilayah Perdagangan dan Jasa Berbasis Agroindustri”, makna pembangunan yang 
dilaksanakan berorientasi pada perdagangan dan jasa dengan menumbuhkan agroindustri sebagai pilar utama. Agroindustri yang dimaksud merupakan kegiatan yang berperan menciptakan nilai tambah, menghasilkan produk untuk dipasarkan /digunakan/ dikonsumsi, meningkatkan daya simpan, menambah pendapatan dan keuntungan produsen, menciptakan lapangan kerja, memperbaiki pemerataan pendapatan serta menarik pembangunan sektor pertanian sebagai sektor penyedia bahan baku. Optimalisasi nilai tambah dicapai dengan pola industri yang berintegrasi langsung dengan usaha tani keluarga dan perusahaan pertanian (RPJPD Kalsel 2005-2025).

Kalimantan Selatan terdiri dari 13 kabupaten/kota, memiliki sumber daya pertanian yang berpotensi mendorong pertumbuhan ekonomi. Berdasarkan Perda No 6 Tahun 2000 tentang RTRWP Kalimantan Selatan, terdapat 3 kawasan andalan di Kalimantan Selatan yaitu : (1) Kawasan Andalan Kandangan dan sekitarnya dengan sektor unggulan pertanian, perkebunan, perikanan dan pariwisata; (2) Kawasan Andalan Banjarmasin Raya dan sekitarnya, kawasan metropolis dengan sektor unggulan pertanian, industri, perkebunan, pariwisata, perikanan dan kelautan, dan; (3) Kawasan Andalan Batulicin dan sekitarnya, dengan sektor unggulan perkebunan, kehutanan, pertanian, industri, dan perikanan.

Kawasan Andalan Kandangan memiliki rata-rata pertumbuhan ekonomi lebih kecil dibandingkan dengan 2 kawasan lainnya, tetapi sangat potensial untuk dikembangkan menjadi kawasan yang berperan dalam mendorong pertumbuhan ekonomi. Potensi tersebut yaitu sebagai kawasan budidaya pertanian tanaman pangan dan hortikulura, budidaya peternakan, budidaya kehutanan, dan kegiatan industri berbasis pertanian. Kontribusi sektor pertanian dan industri di Kawasan Andalan Kandangan berbeda cukup jauh yaitu masing-masing sebesar 23,58\% untuk sektor pertanian dan 3,64\% untuk sektor industri. Kontribusi terbesar diberikan oleh sektor pertambangan dan penggalian sebesar $38,31 \%$, disusul oleh sektor tersier atau jasa-jasa sebesar $34,6 \%$.

\section{METODE}

Penelitian ini dilakukan di Kawasan Andalan Kandangan yang terdiri dari enam kabupaten di Provinsi Kalimantan Selatan, yang dipilih secara sengaja dengan pertimbangan kawasan tersebut merupakan kawasan dengan sektor unggulan pertanian. Enam kabupaten tersebut yaitu: Kabupaten Tapin, Hulu Sungai Selatan (HSS), Hulu Sungai Tengah (HST), Hulu Sungai Utara (HSU), Balangan dan Tabalong. Data yang digunakan dalam penelitian ini adalah data primer dan data sekunder. Data primer didapatkan melalui kuesioner dengan jumlah responden 12 orang dari 2 instansi pemerintah (BAPPEDA dan Dinas Pertanian) masing-masing kabupaten. Data sekunder meliputi data PDRB ADHK 9 sektor tahun 2009 sampai 2013, data PDRB subsektor pertanian tahun 2009 sampai 2013, data produksi tanaman padi dan palawija tahun 2013, data produksi padi dan palawija tahun 2010, dan data infrastruktur atau sarana prasarana.

Analisis entropi digunakan untuk memahami perkembangan suatu wilayah, dengan prinsip adalah semakin beragam aktifitas atau semakin luas jangkauan spasial, maka semakin tinggi entropi wilayah, artimya wilayah tersebut semakin berkembang (Rustiadi et al, 2012). Persamaan umum entropi sebagai berikut :

Dimana :

$$
S=-\sum_{i=1}^{n} \sum_{j=1}^{n} P_{i j} \ln P_{i j}
$$

Keterangan :

$$
\sum_{i=1}^{n} \sum_{j=1}^{n} P_{i j}=1
$$

S : tingkat perkembangan ekonomi wilayah Kawasan Andalan Kandangan

n : jumlah jenis kegiatan (9 sektor)

ij : kategori wilayah/kawasan (6 kabupaten)

$\mathrm{P} \quad$ : peluang atau proposi terjadinya keragaman

Analisis LQ digunakan untuk mengetahui pemusatan suatu aktivitas di suatu wilayah dalam cakupan wilayah agregat yang lebih luas. Penelitian ini menggunakan pemusatan aktifitas setiap kabupaten dalam cakupan wilayah Kawasan Andalan Kandangan. Persamaan model analisis LQ sebagai berikut :

$$
L Q_{i j}=\frac{X_{i j} / X_{i .}}{X_{i j} / X_{m}}
$$

Keterangan:

Xij : adalah nilai indikator aktifitas produksi ke-j pada wilayah kab ke-i

Xi. : adalah jumlah indikator aktifitas produksi di wilayah kab ke-i

X.j : adalah jumlah indikator aktifitas produksi ke-j di kawasan, dan

X.. $\quad$ : adalah penjumlahan nilai indikator seluruh aktifitas produksi di Kawasan Andalan Kandangan

Shift Share Analysis (SSA) merupakan salah satu analisis untuk memahami pergeseran struktur aktifitas dari suatu wilayah dan membandingkan secara relatif dengan suatu referensi (cakupan 
wilayah lebih luas) dalam dua titik waktu. Persamaan SSA sebagai berikut :

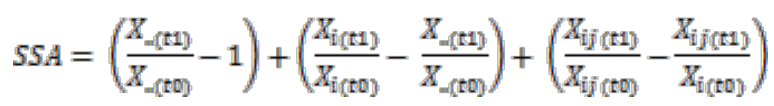

a

b

Keterangan :

$\begin{array}{lll}\text { a } & : & \text { komponen regional share } \\ \text { b } & : & \text { komponen proportional shift } \\ \text { c } & : & \text { komponen differential shift, dan } \\ \text { X.. } & : & \text { nilai total aktifitas wilayah kab secara } \\ & & \text { agregat } \\ \text { X.i } & : & \text { nilai total aktifitas tertentu di unit } \\ & \text { wilayah kab ke-i } \\ \text { Xij } & : & \text { nilai di wilayah kab ke-i dan aktifitas } \\ & & \text { ke-j } \\ \text { t1 } & : & \text { titik tahun akhir (2013) } \\ \text { t0 } & : & \text { titik tahun awal (2010) }\end{array}$

Analisis deskriptif digunakan untuk menjelaskan beberapa bagian berkaitan dengan pemahaman komoditas pertanian untuk industri di Kawasan Andalan Kandangan, bagian tersebut adalah; (1) pewilayahan komoditas, (2) sarana infrastruktur, (3) sumber daya manusia, dan (4) sarana kelembagaan (Nur, 2009).

Analisis SWOT digunakan untuk menggambarkan secara jelas bagaimana peluang dan ancaman dari faktor eksternal yang dihadapi berkaitan dengan pengembangan wilayah berbasis agroindustri dan disesuaikan dengan kekuatan dan kelemahan yang dimiliki. Analisis SWOT dengan prinsip-prinsip pengembangan wilayah meliputi pengamatan kondisi internal dan eksternal (Rangkuti, 2001).

Analitical Hierarchy Process (AHP) merupakan salah satu metode pengambilan keputusan. Model pendukung keputusan ini akan menguraikan masalah multi faktor atau multi kriteria yang kompleks menjadi suatu hirarki. Hirarki didefinisikan sebagai suatu representasi dari sebuah permasalahan yang kompleks dalam suatu struktur multi level dimana level pertama adalah tujuan, yang diikuti level faktor, kriteria, sub kriteria, dan seterusnya ke bawah hingga level terakhir dari alternatif. Dengan hirarki suatu permasalahan yang kompleks dapat diuraikan ke dalam kelompokkelompoknya yang kemudian diatur menjadi suatu bentuk hirarki sehingga permasalahan akan tampak lebih terstruktur dan sistematis (Syaifullah, 2010).

Tahapan-tahapan pengambilan keputusan kebijakan dengan menggunakan analisis AHP yaitu sebagai berikut :

1. Tahapan pertama yaitu, menentukan tujuan, kriteria, subkriteria, aktor dan alternatif yang kemudian disusun dalam sebuah hirarki. Tujuan dari penelitian yaitu menentukan strategi pengembangan ekonomi wilayah berbasis agroindustri di Kawasan Andalan Kandangan. Kriteria yang dipilih yaitu berdasarkan kondisi lapangan dan konsep penerapan strategi industrialisasi pertanian oleh Priyarsono (2011), diantaranya yaitu, (1) memperluas investasi dalam bentuk fisik dan infrastruktur kelembagaan; (2) menghilangkan unsur-unsur idustri pertanian dan perdagangan yang menyebabkan kerusakan pertanian (keberlanjutan); dan kriteria (3) menciptakan perluasan pasar dan perdagangan terbuka. Sub kriteria dari kriteria pertama yaitu, (A) investasi dalam riset dan budaya; (B) investasi sosial dan budaya; dan (C) investasi pemasaran dan jaringan transportasi. Sub kriteria dari kriteria kedua yaitu, (D) pembangunan pabrik industri pertanian berbasis input; (E) pembangunan infrastruktur berdasarkan komoditas unggulan; dan (F) Road Map industri pertanian unggulan. Sub kriteria dari kriteria ketiga yaitu, (G) pemasaran antar daerah; (H) e-marketing, dan ( I) Masterplan Kawasan Andalan Kandangan. Tingkat hirarki berikutnya adalah aktor yang dipilih dalam pengembangan ekonomi wilayah berbasis agrondustri di kawasan agroindustri yaitu, (1) pemerintah, (2) petani/masyarakat, dan (3) swasta/investor. Alternatif strategi yang didapatkan berdasarkan hasil dari analisis SWOT sebelumnya.

2. Tahapan kedua adalah melakukan pembobotan terhadap kriteria dengan perbandingan berpasangan (pairwise comparison). Tahapan kedua

dilakukan untuk setiap tingkatan dalam struktur hirarki, dengan bobot yang digunakan adalah skala yang dibangun oleh Saaty dengan nilai 1 sampai dengan 9. Nilai bobot menggambarkan tingkat kepentingan masing-masing kriteria,

\section{Tabel 1.}

\begin{tabular}{|c|c|}
\hline Nilai & Keterangan \\
\hline 1 & $\begin{array}{l}\text { Faktor A sama penting dengan } \\
\text { Faktor B }\end{array}$ \\
\hline 3 & $\begin{array}{l}\text { Faktor A lebih penting dari } \\
\text { Faktor B }\end{array}$ \\
\hline 5 & $\begin{array}{l}\text { Faktor A jelas lebih penting } \\
\text { dari Faktor B }\end{array}$ \\
\hline 7 & $\begin{array}{l}\text { Faktor A sangat jelas lebih } \\
\text { penting dari Far Aktor B }\end{array}$ \\
\hline 9 & $\begin{array}{l}\text { Faktor A mutlak lebih penting } \\
\text { dari Faktor B }\end{array}$ \\
\hline $2,4,6,8$ & $\begin{array}{l}\text { Apabila ragu-ragu antara dua } \\
\text { nilai elemen yang berdekatan }\end{array}$ \\
\hline $1 /(2 / 9)$ & $\begin{array}{l}\text { Kebalikan dari keterangan nilai } \\
2-9\end{array}$ \\
\hline
\end{tabular}

Sumber : Marimin 2010 
yaitu nilai 1 menggambarkan bahwa dua kriteria yang dibandingkan memiliki tingkat kepentingan yang sama, sedangkan nilai 9 memiliki tingkat kepentingan yang mutlak (Tabel 1).

Berdasarkan Tabel 1, nilai perbandingan A dengan $\mathrm{B}$ adalah 1 (satu) dibagi dengan nilai perbandingan $B$ dengan A. Matriks yang dihasilkan diolah untuk menentukan bobot dari kriteria, yaitu dengan nilai eigen atau eigenvector. Adapun prosedur untuk mendapatkan nilai eigen tersebut yaitu :

(1) Kuadratkan matriks tersebut;

(2) Hitung jumlah nilai dari setiap baris, kemudian lakukan normalisasi;

(3) Hentikan proses tersebut jika perbedaan antara jumlah dari dua perhitungan berturut-turut lebih kecil dari suatu nilai batas tertentu
3. Tahapan ketiga yaitu menyusun prioritas unsur keputusan dan pengaruh setiap unsur dalam tingkatan hirarki tertentu terhadap tujuan utama.

4. Selanjutnya adalah menguji keabsahan nilai dari matriks berpasangan dengan cara menghitung nilai rasio konsistensi. Pada umumnya nilai yang masih dapat diterima yaitu nilai konsistensi sebesar $10 \%$, meskipun terdapat kasus dengan toleransi lebih dari angka tersebut

\section{HASIL DAN PEMBAHASAN}

Perkembangan perekonomian wilayah pada tahun 2009 sampai dengan 2013, untuk 9 sektor di 6 wilayah diperoleh bahwa nilai entropi maksimum yaitu 3,98 (Tabel 2). Nilai Entropi per sektor menunjukan angka yang meningkat dari tahun ke tahun sebesar $0,4 \%$, meskipun nilai rata-rata entropinya belum mencapai nilai maksimum yaitu

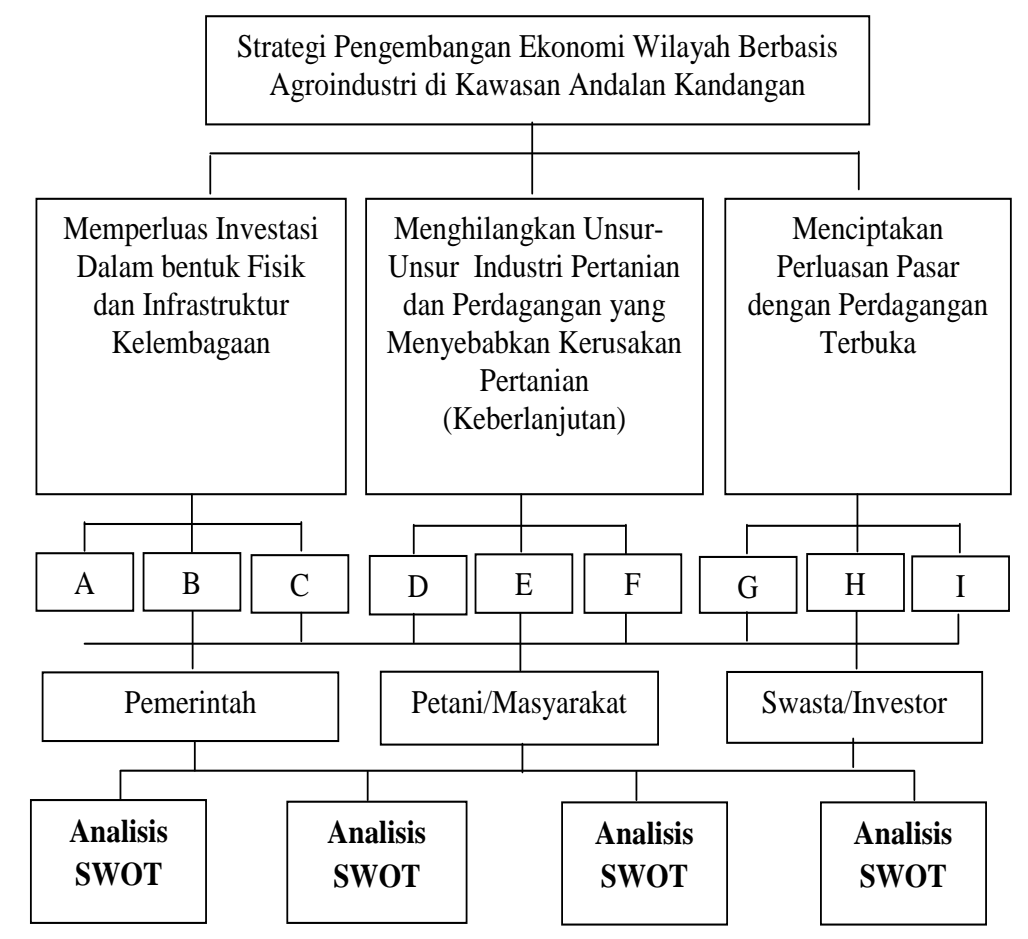

Gambar 1. Struktur AHP Penentuan Prioritas Strategi Pengembangan

Keterangan :

Ekonomi Wilayah Berbasis Agroindustri

A : Investasi dalam riset budidaya

B : Investasi sosial pedesaan \& pendidikan

C : Investasi pemasaran \& transportasi

D : Pembangunan pabrik industri pertanian berbasis input

E : Pembangunan infrastruktur berdasarkan komoditas unggulan

$\mathrm{F}$ : Road Map agroindustri unggulan

$\mathrm{G}$ : Pemasaran antar daerah

$\mathrm{H}$ : E-marketing

I : Masterplan Kawasan Andalan Kandangan 
dengan nilai rata-rata setiap tahun 3,09.

Nilai wilayah dengan aktivitas setiap sektor tertinggi adalah sebesar 0,76 yaitu Kabupaten Tabalong dan terendah 0,41 yaitu Kabupaten Hulu Sungai Utara. Hasil dari nilai sektor dengan aktivitas paling merata di setiap wilayah adalah sebesar 0,81 yaitu sektor pertanian dan terendah 0,01 yaitu sektor listrik, gas dan air bersih. Dengan nilai entropi yang meningkat setiap tahun dan mendekati nilai maksimum, serta memiliki jenis aktivitas ekonomi menunjukkan bahwa Kabupaten Tabalong memiliki sebaran intensitas aktivitas paling merata atau memiliki peluang yang sama dibandingkan dengan 5 kabupaten lainnya. Tingginya nilai entropi tersebut salah satunya dikarenakan besarnya jumlah pendapatan regional Kabupaten Tabalong yaitu sebesar Rp 1.656,12 milyar, merupakan 29,48\% dari total pendapatan regional Kawasan Andalan Kandangan sebesar Rp. 5.616,50 milyar (BPS Kalsel, 2014).

Tabel 2 Hasil Analisis Entropi

\begin{tabular}{lccccccc}
\hline \multicolumn{1}{c}{ Uraian } & \multicolumn{9}{c}{ Nilai Entropi } & Rata-rata & \multirow{2}{*}{ Gap } \\
\cline { 2 - 6 } & 2009 & 2010 & 2011 & 2012 & 2013 & & \\
\hline Entropi Maksimum & 3,98 & 3,98 & 3,98 & 3,98 & 3,98 & 3,98 & \multirow{2}{*}{0,89} \\
Entropi Persektor & 3,08 & 3,08 & 3,08 & 3,09 & 3,10 & 3,09 & \\
Nilai Tertinggi Wilayah & 0,76 & 0,76 & 0,76 & 0,76 & 0,77 & 0,76 & \multirow{2}{*}{0,35} \\
Nilai Terendah Wilayah & 0,41 & 0,41 & 0,41 & 0,41 & 0,40 & 0,41 & \\
Nilai Tertinggi Sektor & 0,83 & 0,82 & 0,81 & 0,80 & 0,79 & 0,81 & \multirow{2}{*}{0,79} \\
Nilai Terendah Sektor & 0,01 & 0,01 & 0,01 & 0,01 & 0,01 & 0,01 & \\
\hline
\end{tabular}

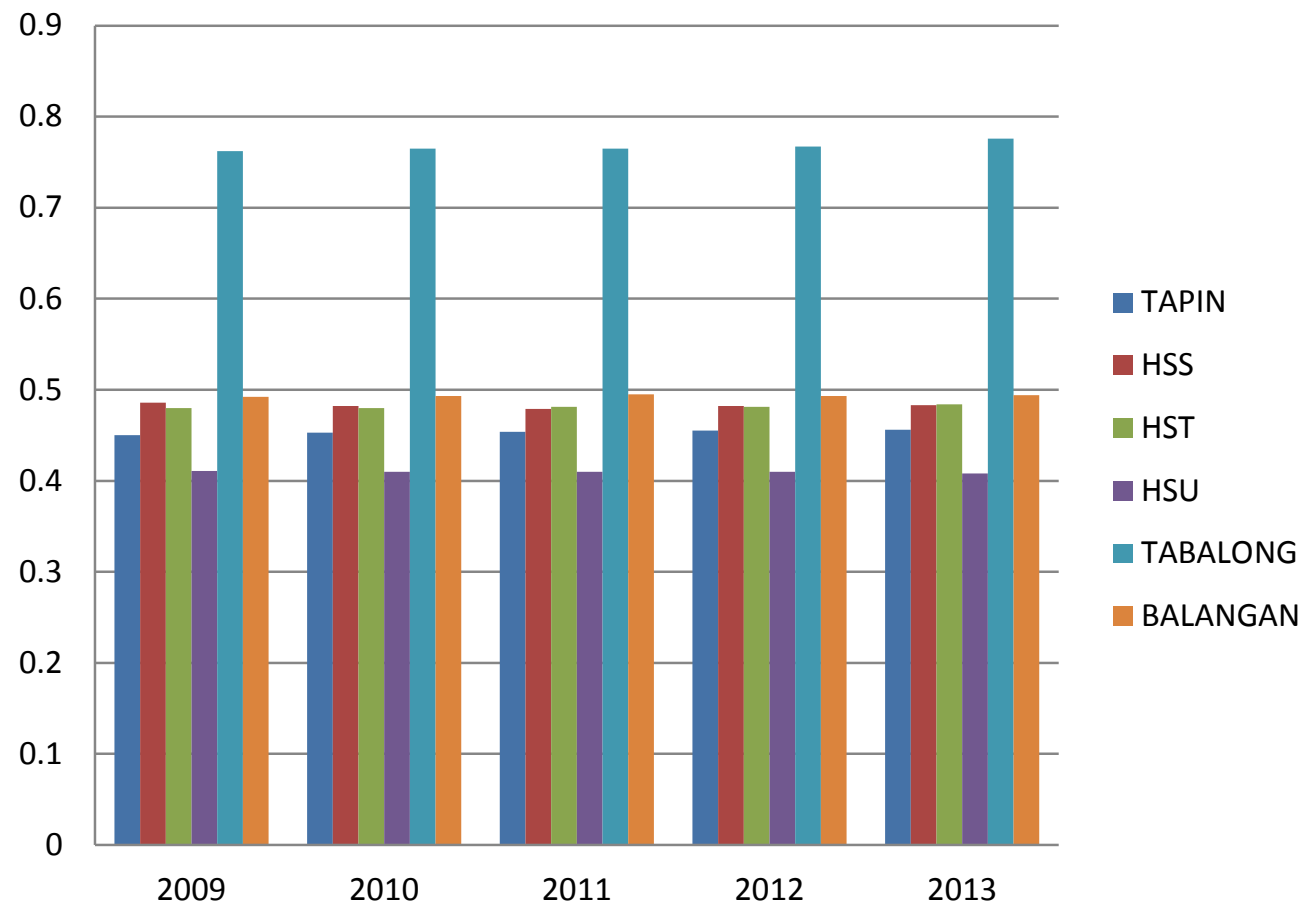

\section{Gambar 2. Unit Pengamatan Setiap Wilayah dari Sebaran Intensitas Aktivitas Setiap Sektor}

setiap sektor yang relatif sama dan merata, dapat dikatakan kawasan tersebut memiliki perkonomian yang semakin berkembang. Peranan sektor yang tertinggi adalah sektor sektor pertanian dan pertambangan penggalian, masing-masing dengan persentase 26,34\% dan 22,93\% (BPS Kalsel, 2014).

Kabupaten Tabalong dengan nilai 0,76 merupakan wilayah dengan nilai tertinggi. Hal ini
Wilayah dengan sebaran paling tidak merata atau memiliki kecenderungan spesifikasi untuk aktivitas tertentu yaitu Kabupaten Hulu Sungai Utara dengan nilai 0,41 yang cenderung menurun dalam 5 tahun. Rendahnya nilai entropi tersebut menggambarkan bahwa dari 9 sektor yang ada, Kabupaten Hulu Sungai Utara memiliki sebaran intensitas paling tidak merata atau memiliki 
kecenderungan aktivitas tertentu yang spesifik yaitu spesifik pada aktivitas sektor pertanian. Dibandingkan dengan 5 kabupaten lainnya aktivitas sektor pertanian di Kabupaten Hulu Sungai Utara adalah yang terendah dan bahkan menurun sebesar 5,54\% (BPS Kalsel,2014).
Andalan Kandangan, sektor pertanian merupakan sektor yang memiliki peranan besar terhadap perkembangan ekonomi di kawasan tersebut. Perkembangan sektor pertanian pada tahun 2009 sampai dengan 2013, berdasarkan hasil analisis entropi untuk 3 subsektor di 6 wilayah diperoleh

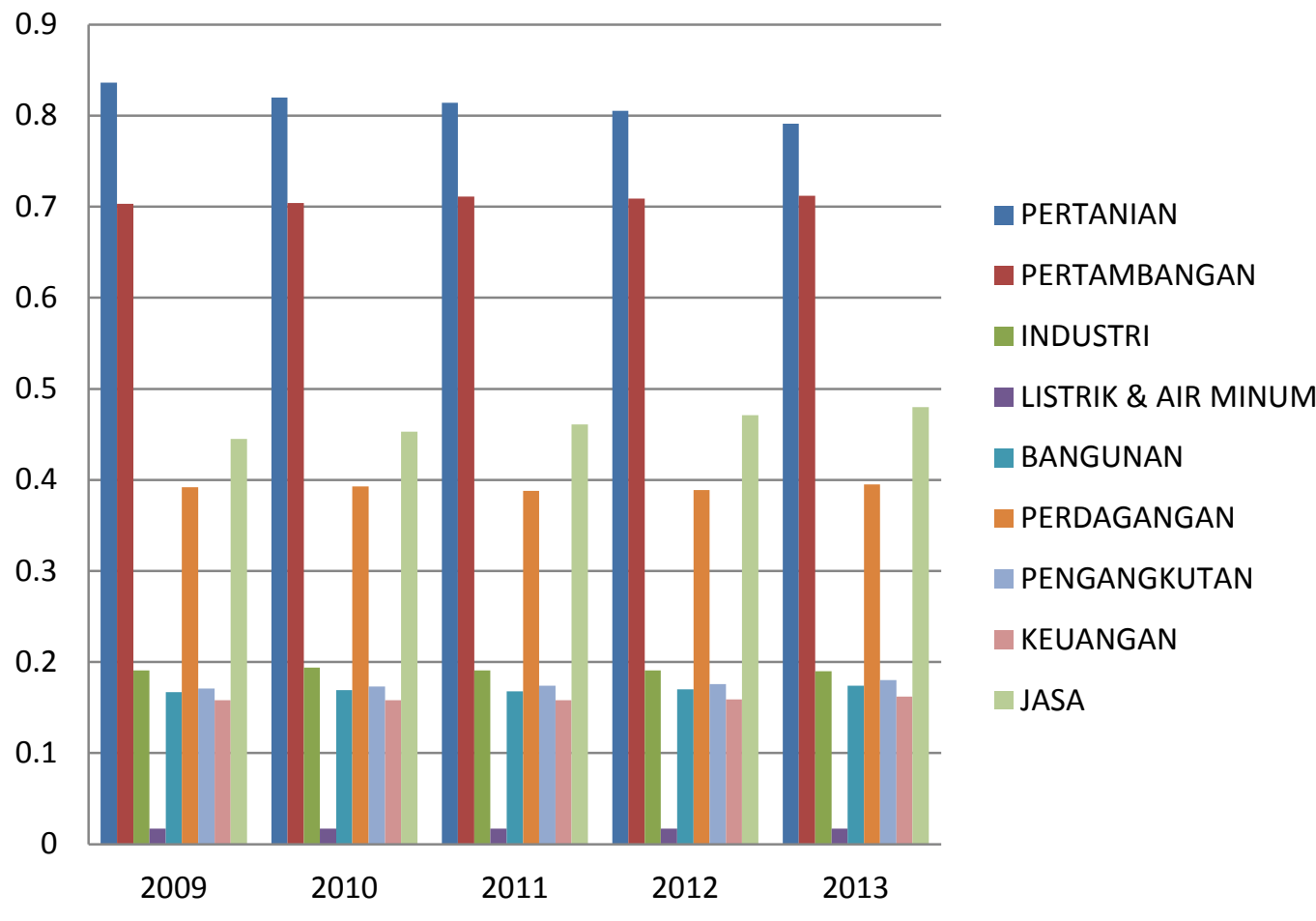

Gambar 3. Unit Pengamatan dari Jumlah Setiap Aktivitas Sektor Pada Setiap Wilayah

Sektor pertanian merupakan sektor dengan nilai tertinggi sebesar 0,81 pada tahun 2009 sampai 2013 (Gambar 3), yang berarti bahwa sektor pertanian memiliki aktivitas dengan intensitas merata diseluruh wilayah. Sementara sektor yang memiliki aktivitas yang cenderung mengalami pemusatan lokasi dengan nilai 0,01 adalah aktivitas sektor listrik, gas dan air bersih. Sektor pertanian cenderung menurun sebesar $0,04 \%$ setiap tahunnya tetapi tidak berpengaruh terhadap posisi sektor pertanian dalam perekonomian Kawasan Andalan Kandangan. Sektor pertanian sangat signifikan unggul dibandingkan dengan 7 sektor lainnya, meskipun terjadi disorientasi pengelolaan karena berkembangnya lahan perkebunan sawit dan pertambangan penggalian. Kontribusi PDRB sektor pertanian terhadap total PDRB Kawasan Andalan Kandangan selama 5 tahun rata-rata sebesar $27 \%$, disusul sektor pertambangan dan sektor jasa masing-masing sebesar $22 \%$ dan 14\%. Berdasarkan hal tersebut peranan sektor pertanian berdasarkan nilai entropi pada tahun 2009 sampai dengan tahun 2013 sangat penting dalam upaya mengembangkan kawasan (BPS Kalsel, 2014).

Berdasarkan pada Tabel 3, hasil analisis perkembangan perkonomian wilayah di Kawasan bahwa nilai entropi maksimum yaitu 2,89. Wilayah dengan aktivitas setiap subsektor tertinggi adalah sebesar 0,47 dan terendah 0,33 sedangkan nilai subsektor dengan aktivitas paling merata di setiap wilayah adalah sebesar 1,45 dan terendah 0,38.

Nilai entropi subsektor pada tahun 2009 sampai dengan 2013 sebesar 2,52 sudah mendekati nilai maksimum. Hal ini menunjukkan bahwa tingkat penyebaran aktivitas setiap subsektor di seluruh wilayah Kawasan Andalan Kandangan relatif merata. Nilai entropi dari 3 subsektor pertanian pada tahun 2009 lebih tinggi yaitu sebesar 2,52 dan menurun pada tahun 2013 menjadi sebesar 2,51.

Pada Gambar 4, Kabupaten Hulu Sungai Tengah merupakan wilayah dengan nilai entropi wilayah pada subsektor pertanian tertinggi yaitu 0,47 pada tahun 2009 sampai 2013. Hal ini menunjukkan bahwa Kabupaten Hulu Sungai Tengah memiliki sebaran intensitas aktivitas subsektor pertanian paling merata atau memiliki peluang perkembangan seluruh aktivitas subsektor relatif sama di Kawasan Andalan Kandangan dibandingkan dengan 5 kabupaten lainnya. Kondisi ini relevan dengan lapangan pekerjaan masyarakatnya yang hampir 70\% berusaha di bidang pertanian, baik itu tanaman 
pangan dan holtikultura, perkebunan, peternakan dan perikanan (BPS HST, 2014).

Pemerintah Kabupaten Hulu Sungai Tengah menetapkan sektor pertanian sebagai prioritas pembangunan dengan harapan dapat memacu lebih cepat perbaikan ekonomi masyarakat setempat (Renstrakab HST, 2013). Kabupaten Hulu Sungai Utara merupakan wilayah dengan nilai entropi terendah yaitu 0,33 yang berarti bahwa wilayah dengan sebaran intensitas aktivitas subsektornya paling tidak merata atau memiliki kecenderungan aktivitas subsektor yang spesifik.

Berdasarkan pada Gambar 5, perkembangan sektor pertanian selama 5 tahun didominasi oleh subsektor pertanian tanaman bahan makanan yang nilai entropinya berbeda secara signifikan dibandingkan dengan 2 subsektor lainnya. Nilai pemusatan lokasi adalah subsektor peternakan dan hasil lainnya dengan nilai entropi 0,38.

Berdasarkan nilai entropi, subsektor tanaman bahan makanan memiliki peluang yang cukup besar untuk dikembangkan sebagai subsektor unggulan bagi peningkatan ekonomi Kawasan Andalan Kandangan. Sebagai subsektor unggulan atau memasuki stadia marketable surplus sesuai dengan strategi demand side, subsektor tanaman bahan makanan mengisyaratkan untuk dikembangkan menjadi produk industri. Adanya industri hasil pertanian akan menyebabkan peningkatan permintaan hasil pertanian, sehingga akan meningkatkan pendapatan wilayah tersebut (Rustiadi et al, 2011).

Pemilihan tanaman bahan makanan yaitu tanaman padi dan palawija menjadi komoditas

Tabel 3. Hasil Analisis Entropi Subsektor Pertanian

\begin{tabular}{lccccccc}
\hline \multicolumn{1}{c}{ Uraian } & \multicolumn{9}{c}{ Nilai Entropi } & Rata- & Gap \\
\cline { 2 - 5 } & 2009 & 2010 & 2011 & 2012 & 2013 & rata & \\
\hline Entropi Maksimum & 2,89 & 2,89 & 2,89 & 2,89 & 2,89 & 2,89 & \multirow{2}{*}{0,36} \\
Entropi Persubsektor & 2,52 & 2,52 & 2,52 & 2,52 & 2,51 & 2,52 & \\
Nilai Tertinggi Wilayah & 0,47 & 0,47 & 0,47 & 0,46 & 0,47 & 0,47 & 0,13 \\
Nilai Terendah Wilayah & 0,33 & 0,33 & 0,33 & 0,33 & 0,33 & 0,33 & \\
Nilai Tertinggi Subsektor & 1,45 & 1,45 & 1,46 & 1,45 & 1,46 & 1,45 & \multirow{2}{*}{1,07} \\
Nilai Terendah Subsektor & 0,39 & 0,39 & 0,38 & 0,38 & 0,38 & 0,38 & \\
\hline
\end{tabular}

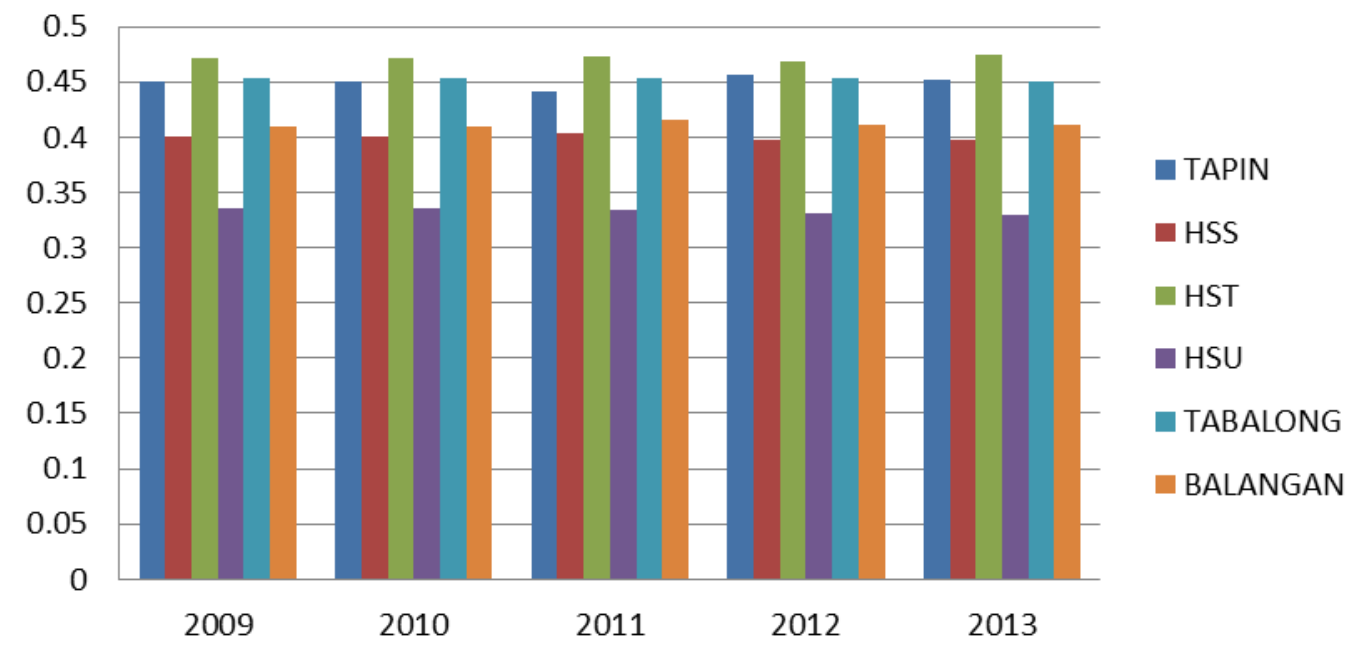

\section{Gambar 4. Unit Pengamatan Setiap Wilayah dari Sebaran Intensitas Aktivitas Setiap Subsektor}

entropi setiap subsektor pada tahun 2009 sampai 2013 menunjukkan bahwa subsektor pertanian tanaman bahan makanan memiliki indeks tertinggi sebesar 1,45. Hal ini berarti bahwa subsektor pertanian tanaman bahan makanan memiliki aktivitas dengan intensitas merata diseluruh wilayah.Sementara subsektor pertanian yang memiliki aktivitas yang cenderung terjadi unggulan di Kawasan Andalan Kandangan berdasakan sebaran aktivitasnya yang cukup merata disetiap wilayah kabupaten dengan nilai yang sangat signifikan.Tanaman padi dan palawija juga merupakan komoditas unggulan pertanian di Kalimantan Selatan khususnya komoditas padi (BKP Kalimantan Selatan, 2010). Berdasarkan hal tersebut maka penentuan komoditas unggulan dan wilayah 
basis menggunakan data subsektor pertanian tanaman bahan makanan dengan 7 komoditas padi dan palawija.

\section{Gambaran Potensi Komoditas Pertanian dan Sarana Infrastruktur Kawasan Andalan Kandangan}

agroindustri. Berdasarkan data-data sarana infrastruktur pendukung pengembangan agroindustri tersebut, wilayah atau kabupaten yang paling memenuhi syarat untuk sarana infrastruktur yaitu Kabupaten Hulu Sungai Utara dan Kabupaten Hulu Sungai Tengah. Berikut adalah dukungan infrastruktur dan kabupaten dengan dukungan paling baik. (Tabel 5)

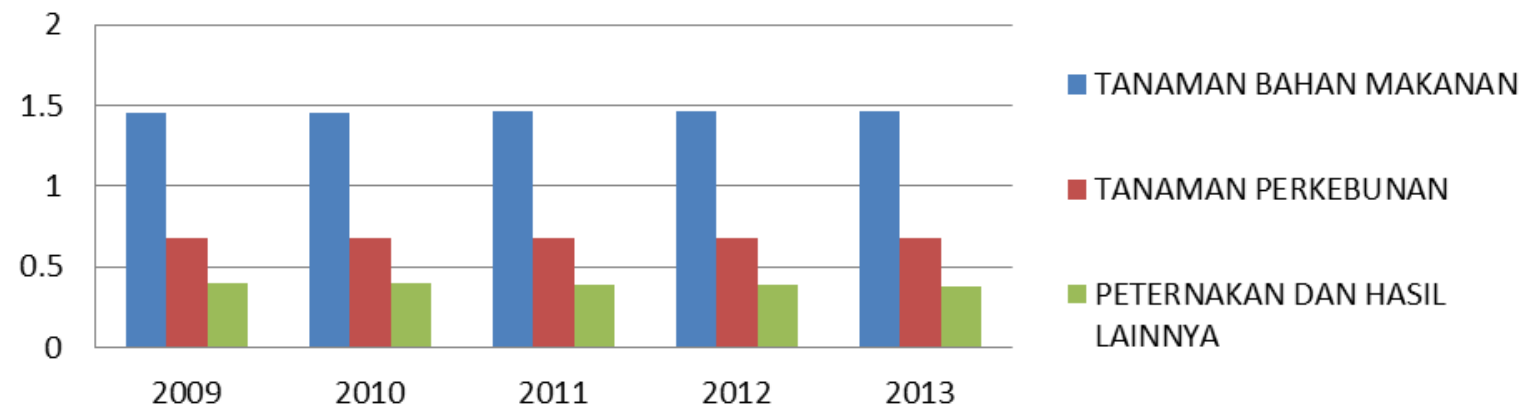

Gambar 5. Unit Pengamatan dari Jumlah Setiap Aktivitas Subsektor Pada Setiap Wilayah

\section{Pewilayahan Komoditas Berdasarkan Subsektor Pertanian Unggulan}

Berdasarakan hasil analisis LQ, 5 dari 6 pada Tabel 4, komoditas padi dan palawija rata-rata merupakan sektor basis di Kawasan Kandangan, hasil sementara dari nilai LQ tersebut jika dikategorikan berdasarkan nilai LQ tertinggi maka kacang kedelai merupakan komoditas unggulan dengan nilai rata-rata kawasan yaitu 1,31. Dalam penelitian ini selain menggunakan analsis LQ juga digunakan analisis SSA untuk mengetahui daya saing dari setiap komoditas tersebut.

\section{Sarana Infrastruktur}

Dukungan prasarana jalan berdasarkan kondisi dan kelas jalan serta ketersediaan lisrik dan air bersih merupakan bagian dari sarana

\section{Sumber Daya Manusia}

Gambaran dukungan SDM setiap kabupaten berdasarkan hasil analisis kualitatif dari data-data SDM untuk pengembangan agroindustri yang paling baik yaitu Kabupaten Hulu Sungai Tengah dan Kabupaten Hulu Sungai Selatan.

Dukungan SDM untuk kegiatan agroindustri dengan kualifikasi tingkat pendidikan SLTP keatas serta jumlah pencari kerja cukup memadai di Kawasan Andalan Kandangan. Didalam penjelasan Tabel 6 adalah dukungan SDM dan kabupaten dengan dukungan SDM paling baik.

\section{Sarana Kelembagan}

Gambaran sarana kelembagaan setiap kabupaten di Kawasan Andalan Kandangan berdasarkan analisis kualitatif dari data-data sarana

Tabel 4. Komoditas Unggulan Hasil Analisis LQ dan SSA

\begin{tabular}{|c|c|}
\hline Komoditas Unggulan & Keterangan \\
\hline Padi & Berdaya saing dan potensial dikembangkan agroindustri \\
\hline Jagung & Berdaya saing dan potensial dikembangkan agroindustri \\
\hline
\end{tabular}

Tabel 5 Sarana Infrastruktur

\begin{tabular}{cll}
\hline No & \multicolumn{2}{c}{ Sarana Infrastruktur Dasar } \\
\hline 1. & Jalan (kondisi dan kelas jalan) & Tabalong dan Hulu Sungai Tengah \\
2. & Listrik & Hulu Sungai Tengah dan Hulu Sungai Utara \\
3. & Air & Hulu Sungai Tengah dan Hulu Sungai Utara \\
\hline
\end{tabular}

infrastruktur dasar untuk pengembangan kelembagaan untuk pengembangan agroindustri, 
maka kabupaten dengan kriteria paling baik yaitu Kabupaten Tapin, berikut adalah dukungan sarana kelembagaan dan kabupaten dengan dukungan sarana kelembagaan paling baik. (Tabel 7) komprehensif dan terpadu; (4) mempunyai keterkaitan kuat ke depan dan ke belakang; serta (5) dilaksanakan sesuai dengan prinsip-prinsip otonomi dan desentralisasi (Bappenas dalam Wibowo, 2008).

Tabel 6. Dukungan SDM

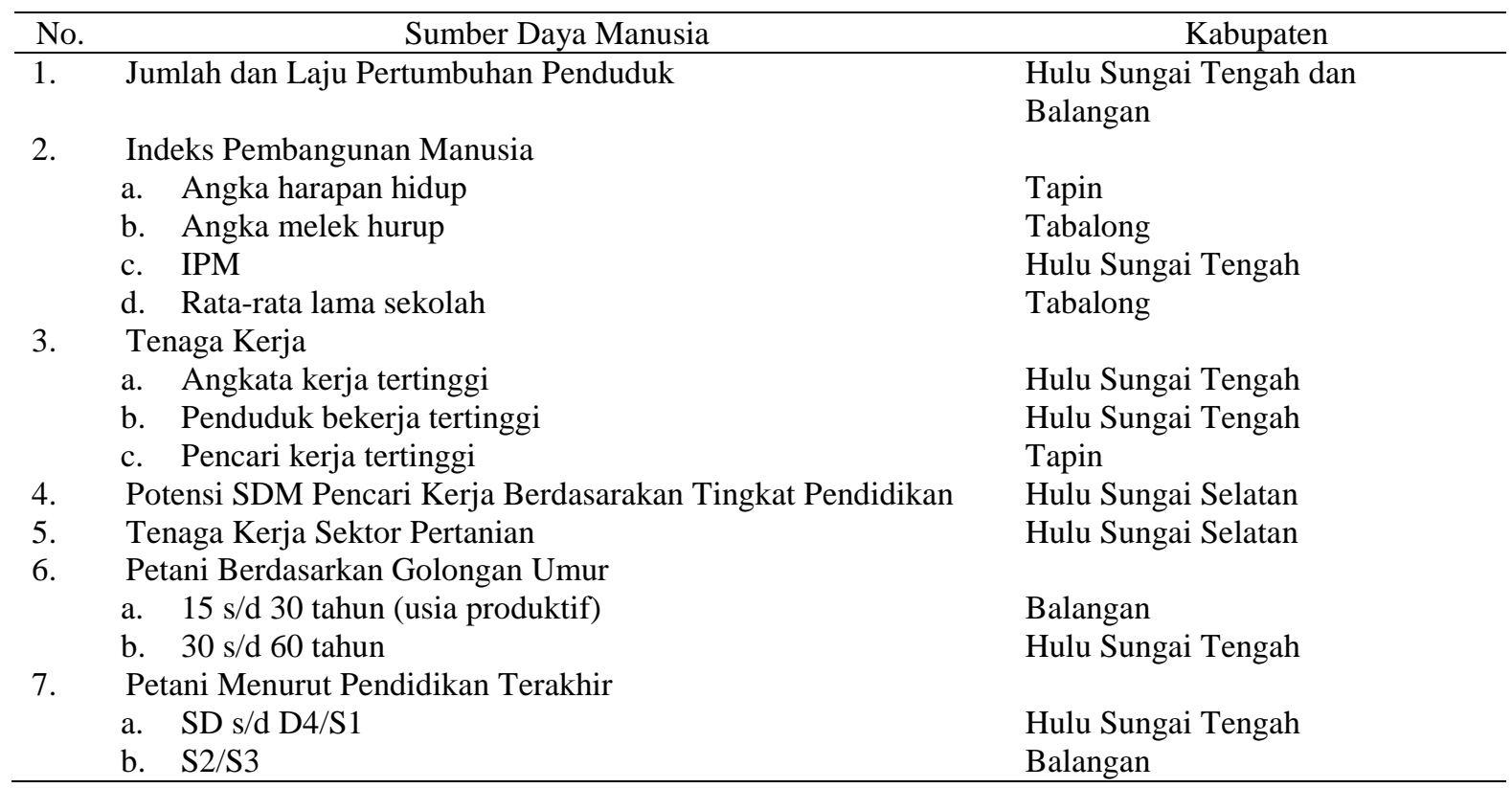

Tabel 7. Sarana Kelembagaan

\begin{tabular}{lll}
\hline No. & \multicolumn{1}{c}{ Kelembagaan } & \multicolumn{1}{c}{ Kabupaten } \\
\hline 1. & Dukungan Pemerintah Kabupaten (Visi dan Misi RPJMD) & Hulu Sungai Selatan \\
2. & Kelembagaan Keuangan (pemberian modal) & \\
& a. Perbankan & Tapin \\
& b. Pemerintah (DPM-LUEP) & Hulu Sungai Utara \\
4. & KUD dan Non KUD & Tapin \\
5. & Kelompok Tani & Hulu Sungai Tengah \\
\hline
\end{tabular}

\section{Strategi Pengembangan Ekonomi Wilayah Berbasis Agroindustri}

Pengembangan suatu wilayah harus berdasarkan pengamatan terhadap kondisi internal, sekaligus mengantisipasi perkembangan eksternal. Faktor-faktor internal mencakup pola-pola pengembangan Sumber Daya Manusia (SDM), informasi pasar sumber daya modal dan investasi, kebijakan dalam investasi, pengembangan infrastruktur, pengembangan kemampuan kelembagaan lokal dan kepemerintahan, serta berbagai kerjasama dan kemitraan. Sedangkan faktor eksternal meliputi kesenjangan wilayah dan pengembangan kapasitas otonomi daerah, perdagangan bebas dan otonomi daerah itu sendiri. Sehingga konsep pengembangan wilayah paling tidak didasarkan pada prinsip-prinsip antara lain : (1) berbasis sektor unggulan; (2) dilakukan atas dasar karakteristik daerah; (3) dilakukan secara
Berdsarkan prinsip-prinsip dalam konsep pengembangan wilayah tersebut maka penentuan sektor unggulan menjadi hal yang sangat penting sebagai dasar perencanaan pembangunan daerah, hal tersebut dikarenakan daerah memiliki kesempatan dan wewenang untuk membuat strategi kebijakan yang sesuai dengan potensi daerah agar dapat mempercepat pembangunan daerah untuk meningkatkan kesejahteraan masyarakat. Menurut Rachbini dalam Ebtian (2011) data PDRB merupakan informasi yang sangat penting untuk mengetahui output pada sektor ekonomi dan melihat pertumbuhan di suatu wilayah. Dengan bantuan data PDRB, maka akan dapat ditentukan perkembangan perekonomian suatu wilayah serta sektor unggulan dari wilayah tersebut.

Perencanaan pembangunan ekonomi dapat disusun dengan memperhatikan kondisi dan potensi sektoral di wilayah tersebut sehingga perencanaan pembangunan yang realisitis dapat dilakukan. Pembangunan ekonomi akan optimal bila didasarkan 
pada keunggulan komparatif dan keunggulan kompetitif. Keunggulan komparatif lebih menekankan kepemilikan sumber daya ekonomi, sosial, politik dan kelembagaan suatu daerah, seperti; kepemilikan sumber daya alam, sumber daya manusia, infrastruktur dan lain-lain. Sementara keunggulan kompetitif lebih menekankan efisiensi perekonomian Kawasan Andalan Kandangan semakin berkembang dengan dominasi peranan sektor pertanian dan subsektor tanaman bahan makanan serta komoditas padi dan palawija sebagai komoditas unggulan. Selain berdasarkan hasi analisis entropi, LQ dan SSA, analisis deskriptif untuk merumuskan strategi juga didukung oleh sumber-

\section{Tabel 8. Matrik SWOT}

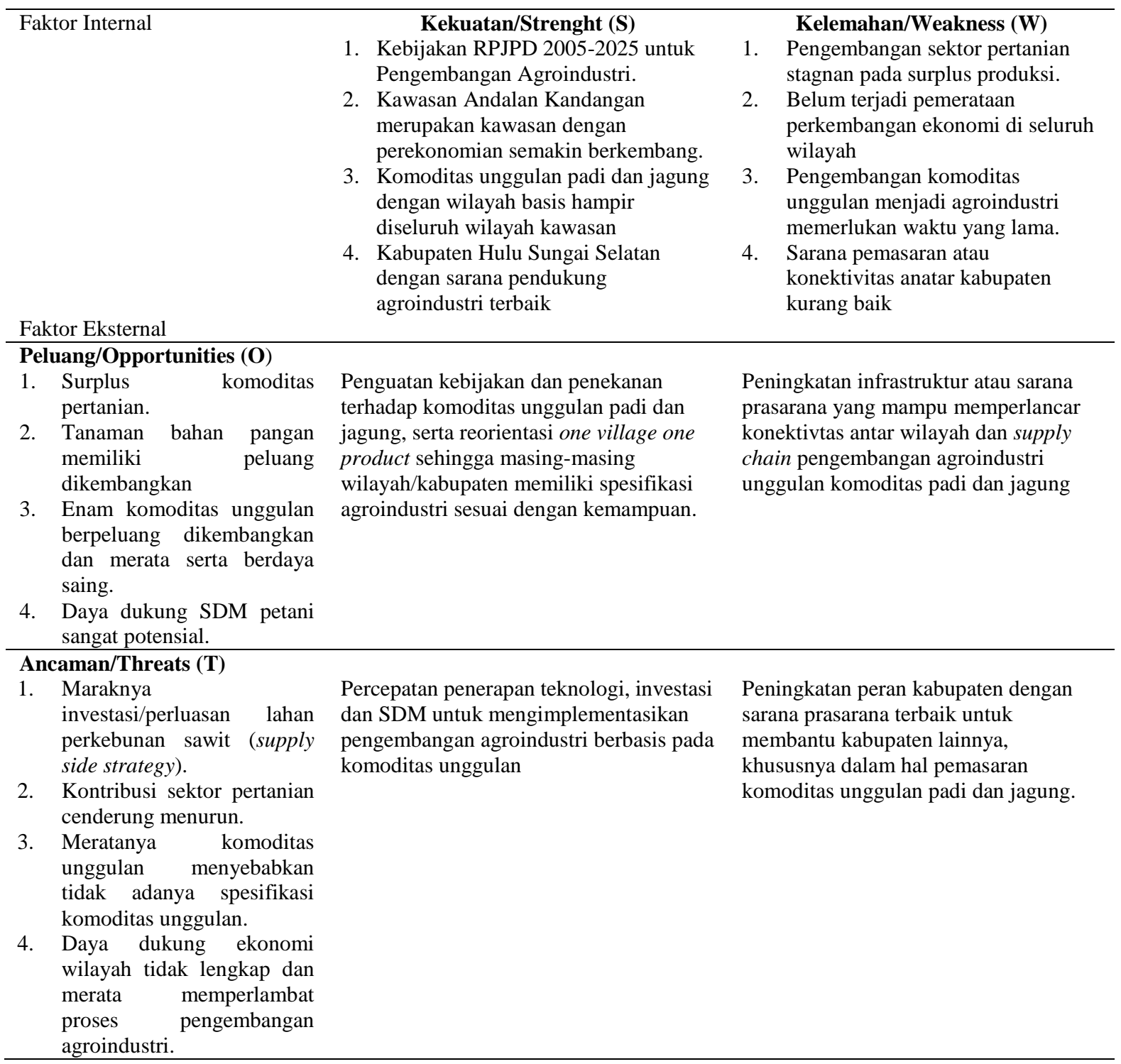

pengelolaan (manajemen, perencanaan, pelaksanaan dan pengawasan) penggunaan sumber-sumber tersebut dalam produksi, konsumsi maupun distribusi (Purnomowati dan Sopanah, 2014).

Sama halnya dengan upaya pengembangan wilayah di Kawasan Andalan Kandangan dapat pula dilihat berdasarkan kontribusi sektoral terhadap PDRB kawasan tersebut. Kontribusi sektoral dapat menggambarkan perkembangan perekonomian yang dapat dijadikan landasan strategi pengembangan wilayah. Berdasarakan hasil analisis entropi pada analisis sebelumnya, menunjukkan perkembangan sumber atau informasi berkaitan dengan daya dukung ekonomi wilayah diantaranya, sarana infrastruktur, sumber daya manusia dan kelembagaan serta keterkaitan antar wilayah di kawasan tersebut. Identifikasi atau gambaran perkembangan perekonomian berdasarkan hasil analisis entropi, LQ, SSA dan informasi berkaitan dengan sarana infrastruktur wilayah akan menjadi dasar penentuan strategi pengembangan wilayah berbasis agroindustri di Kawasan Andalan Kandangan dengan menggunakan analisis SWOT dan AHP. 
Metode ini dimulai dengan mendefinisikan tujuan dari penelitian yaitu menyusun strategi penegmbangan wilayah berbasis agroindustri di Kawasan Andalan Kandangan. Berdasarkan tujuan tersebut kemudian menyususn matriks SWOT sesuai dengan prinsip-prinsip pengembangan wilayah meliputi pengamatan kondisi internal dan eksternal. faktor, ketiga adalah kriteria, keempat sub kriteria yaitu aktor dan terakhir adalah alternatif yaitu pemilihan strategi kebijakan berdasarkan hasil dari tabel SWOT (Tabel 8).

Berdasarkan hasil dari analisis SWOT, analisis entropi, LQ, SSA dan informasi sarana prasarana pendukung kegiatan agroindustri serta pendapat dari

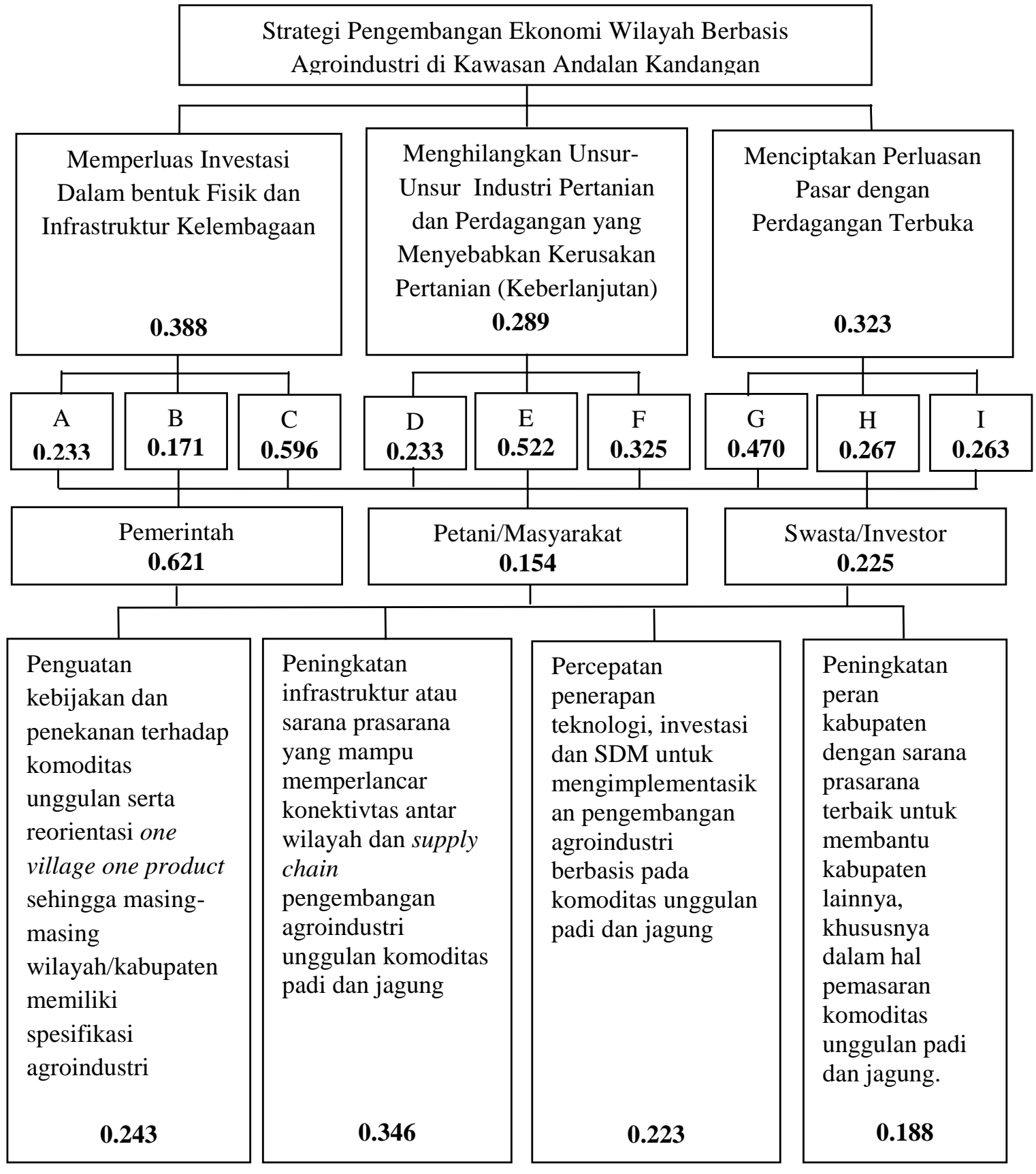

Gambar 6. Hirarki AHP dan Hasilnya

Berdasarkan hasil dari matriks SWOT tersebut, maka metode AHP digunakan untuk menentukan pemilihan strategi kebijakan yang tepat dengan menguraikan masalah multi faktor menjadi suatu hirarki. Hirarki tersebut meliputi multi level yaitu level pertama adalah tujuan, kedua adalah level
Priyarsono (2011), maka dilanjutkan dengan penggunaan metode AHP. AHP digunakan untuk menentukan prioritas dari strategi pengembangan wilayah berbasis agroindustri di Kawasan Andalan Kandangan yang disusun berdasarkan hirarki 
masalah dan pendapat responden ahli. Berikut adalah diagram hirarki dari metode AHP (gambar 6).

\section{KESIMPULAN}

1. Perkembangan ekonomi Kawasan Andalan Kandangan cukup berkembang yang didominasi oleh sektor pertanian yaitu subsektor tanaman bahan makanan.

2. Potensi komoditas unggulan di 6 Kabupaten di Kawasan Andalan Kandangan cukup seragam. Komoditas unggulan tanaman bahan makanan yang merata di seluruh kabupaten yaitu komoditas padi dan jagung.

3. Berdasarkan sarana infrastruktur, SDM, dan kelembagaan, menggambarkan rata-rata kemampuan setiap kabupaten masih sangat kurang dalam mendukung kegiatan pengembangan agroindustri.

4. Rumusan strategi kebijakan untuk mengembangkan wilayah berbasis agroindustri di kawasan andalan Kandangan yaitu dengan meningkatkan infrastruktur atau sarana prasarana yang mampu memperlancar konektivitas antar wilayah. Pelaksanaan strategi tersebut menjadi agenda penting bagi pemerintah daerah sebagai aktor utama dalam pengembangan agroindustri di Kawasan Kandangan .

Implikasi Kebijakan:

1. Pemerintah daerah Provinsi Kalimantan Selatan dapat mengaplikasikan strategi pengembangan wilayah berbasis agroindustri di Kawasan Andalan Kandangan.

2. Perlunya mengoptimalkan kerjasama antar wilayah/kabupaten di Kawasan Andalan Kandangan dalam segala aspek, diantaranya sosial dan pendidikan serta penerapan teknologi.

3. Perlu adanya penelitian lanjutan berkaitan dengan aspek penunjang lainnya guna mendukung pengembangan wilayah berbasis agroindustri.

\section{Daftar Pustaka}

Balitbangda dan Lemlit Unlam. 2011. Penyusunan Rencana Revitalisasi Kawasan Sentra Produksi/Sentra Agribisnis di Kalimantan Selatan. Pemerintah Provinsi Kalimantan Selatan. Banjarmasin.

BPS, Badan Pusat Statistik Provinsi Kalimantan Selatan, 2014.

BKP, Badan Ketahanan Pangan Provinsi Kalimantan Selatan, 2012.

Jhingan M.L. 2012. Ekonomi Pembangunan dan Perencanaan. PT. Raja Grafindo Persada. Jakarta.

Nur, MS. 2009. Agroindustri Untuk Otonomi Daerah, Strategi Pengembangan Kemitraan Agroindustri Terpadu di Era Otonomi Daerah. Calprint Indonesia. Jakarta.
Pemerintah Daerah Provinsi Kalimantan Selatan , 2011. Perda. No 17 Tahun 2009 tentang RPJPD Kalimantan Selatan. Banjarmasin.

Panuju DR dan Rustiadi E. 2012. Teknik Analisis Perencanaan Pengembangan Wilayah. Departemen Ilmu Tanah dan Sumberdaya Lahan IPB. Bogor Bisnis

Priyarsono DS. 2011.Dari Pertanian Ke Industri, Analisi Pembangunan dalam Perspektif Ekonomi Regional. IPB Press. Bogor.

Rangkuti R. 2001. Analisis SWOT Teknik Membedah Kasus Bisnis. PT. Gramedia Pustaka Utama. Jakarta.

Rustiadi E, Saefulhaim S, Panuju DR. 2011. Perencanaan dan Pengembangan Wilayah. Yayasan Pustaka Obor Indonesia. Jakarta.

Syaifullah. 2010. Pengenalan Analitical Hierarchy Process. Syaifullah08.Wordpress.com. 